\title{
Methodiek schoolverlatersinformatiesysteem 2002
}

Citation for published version (APA):

Huijgen, T. G. (2003). Methodiek schoolverlatersinformatiesysteem 2002. Researchcentrum voor Onderwijs en Arbeidsmarkt, Faculteit der Economische Wetenschappen. ROA Working Papers No. 3 https://doi.org/10.26481/umarow.2003003

Document status and date:

Published: 01/01/2003

DOI:

10.26481/umarow.2003003

Document Version:

Publisher's PDF, also known as Version of record

\section{Please check the document version of this publication:}

- A submitted manuscript is the version of the article upon submission and before peer-review. There can be important differences between the submitted version and the official published version of record.

People interested in the research are advised to contact the author for the final version of the publication, or visit the DOI to the publisher's website.

- The final author version and the galley proof are versions of the publication after peer review.

- The final published version features the final layout of the paper including the volume, issue and page numbers.

Link to publication

\footnotetext{
General rights rights.

- You may freely distribute the URL identifying the publication in the public portal. please follow below link for the End User Agreement:

www.umlib.nl/taverne-license

Take down policy

If you believe that this document breaches copyright please contact us at:

repository@maastrichtuniversity.nl

providing details and we will investigate your claim.
}

Copyright and moral rights for the publications made accessible in the public portal are retained by the authors and/or other copyright owners and it is a condition of accessing publications that users recognise and abide by the legal requirements associated with these

- Users may download and print one copy of any publication from the public portal for the purpose of private study or research.

- You may not further distribute the material or use it for any profit-making activity or commercial gain

If the publication is distributed under the terms of Article $25 \mathrm{fa}$ of the Dutch Copyright Act, indicated by the "Taverne" license above, 
Methodiek Schoolverlatersinformatiesysteem 2002

ROA-W-2003/3

Timo Huijgen

Researchcentrum voor Onderwijs en Arbeidsmarkt

Faculteit der Economische Wetenschappen en Bedrijfskunde Universiteit Maastricht

Maastricht, september 2003 
ISBN 90-5321-377-5

Sec03.150.doc 


\section{Inhoud}

Bladzijde

Voorwoord

1 Inleiding 1

2 Schoolverlatersonderzoeken 1

3 Vragenlijsten 2

$4 \quad$ Dataverwerking en weging 3

5 Dekkingsgraad en respons $\quad 7$

6 Invoering nieuwe vragenlijsten 14

$\begin{array}{lll}7 & \text { Evaluatie nieuwe vragenlijsten } & 16\end{array}$

8 Besluit 20

$\begin{array}{ll}\text { Literatuur } & 21\end{array}$

Bijlage A: Kernvragenlijst 23

$\begin{array}{ll}\text { Bijlage B: Schema schoolverlatersonderzoeken } & 25\end{array}$

Bijlage C: Competentievragen 26 



\section{Voorwoord}

Dit werkdocument gaat in op de methodiek die in het uitvoeringsjaar 2002 gehanteerd wordt binnen de schoolverlatersonderzoeken zoals die door het ROA worden uitgevoerd. Het betreft de enquêtes Registratie van Uitstroom en Bestemming van Schoolverlaters (RUBS), HBOMonitor en WO-Monitor. Deze enquetes zijn sinds 1996 in vergaande mate geïntegreerd in het Schoolverlatersinformatiesysteem (SIS), waardoor een vergelijkbaar systeem ontstaan is met gegevens over schoolverlaters uit vrijwel het gehele secundair en tertiair onderwijs. In het kader van het onderzoek binnen dit informatiesysteem is onder andere het rapport en de statistische bijlage van Schoolverlaters tussen onderwijs en arbeidsmarkt 2002 gepubliceerd. Daarnaast zijn er nog drie specifieke rapportages, te weten een rapport over de arbeidsmarktpositie van afgestudeerden van het $\mathrm{HBO}$, een rapport over de arbeidsmarktpositie van afgestudeerden van het kunstvakonderwijs en een rapport over de afgestudeerden van het WO.

SIS 2002 is financieel mogelijk gemaakt door de Ministeries van Onderwijs, Cultuur en Wetenschappen, Sociale Zaken en Werkgelegenheid en Landbouw, Natuurbeheer en Visserij, het Expertisecentrum voor Loopbaanvraagstukken LDC, de HBO-Raad, de VSNU en de deelnemende onderwijsinstellingen. Bij de uitvoering van het onderzoek is samengewerkt met DESAN Research Solutions te Amsterdam en STOAS Onderzoek te Wageningen. Binnen het ROA is de projectleiding van SIS in handen van dr. R.K.W. van der Velden en dr. M.H.J. Wolbers. Dit werkdocument is samengesteld door drs. T.G. Huijgen. Verder hebben aan SIS 2002 meegewerkt: dr. J.P. Allen, P.J.E.G. van der Kolk, drs. G.W.M. Ramaekers, E.M.H.P. Soudant en dr. H.F. Vaatstra (allen werkzaam bij ROA), alsmede drs. M.C.M.Th. van Alphen, drs. H. van Dongen en drs. R. Tjemmes (allen werkzaam bij DESAN Research Solutions). 



\section{Inleiding}

Door het ROA worden jaarlijks drie grootschalige schoolverlatersonderzoeken uitgevoerd. In de eerste plaats betreft dit een onderzoek onder de schoolverlaters van het algemeen voortgezet onderwijs (AVO), het voorbereidend beroepsonderwijs (VBO) ${ }^{1}$, de beroepsopleidende leerweg (BOL) en de beroepsbegeleidende leerweg (BBL) van het secundair beroepsonderwijs aan de hand van de enquête Registratie van Uitstroom en Bestemming van Schoolverlaters (RUBS). In de tweede plaats is dit een onderzoek onder de afgestudeerden van het Hoger Beroepsonderwijs (HBO) via de HBO-Monitor. In de derde plaats wordt onderzoek verricht onder de afgestudeerden van de universiteiten (WO-Monitor). Samen vormen deze schoolverlatersonderzoeken de basis voor een aantal landelijke publicaties, zoals het rapport en de statistische bijlage Schoolverlaters tussen onderwijs en arbeidsmarkt 2002 en de rapporten De arbeidsmarktpositie van afgestudeerden van het hoger beroepsonderwijs; HBO-Monitor 2002, De arbeidsmarktpositie van afgestudeerden van het Kunstenonderwijs; Kunsten-Monitor 2002; en het tweejaarlijkse rapport naar aanleiding van de WO-Monitor.

Dit werkdocument vormt een methodologische verantwoording op de reeds verschenen en nog te verschijnen rapporten. Er zal met name worden ingegaan op de gehanteerde methodiek, de respons en de ingevoerde vernieuwing van de vragenlijsten. De opzet van dit werkdocument is als volgt. Allereerst wordt in paragraaf 2 een uiteenzetting gegeven over het doel en de opzet van de schoolverlatersonderzoeken. In paragraaf 3 wordt ingegaan op de vragenlijsten. In paragraaf 4 wordt ingegaan op de dataverwerking en de weging van de gegevens. Vervolgens wordt in paragraaf 5 een overzicht gegeven van de dekkingsgraad en de respons. Paragraaf 6 gaat nader in op de redenen die ten grondslag liggen aan de ingevoerde vernieuwing van de vragenlijsten. In paragraaf 7 wordt deze vernieuwing geëvalueerd. Ten slotte worden in paragraaf 8 de belangrijkste conclusies van dit werkdocument kort samengevat.

\section{Schoolverlatersonderzoeken}

Doel

De schoolverlatersenquêtes van het ROA zijn gericht op het monitoren en analyseren van de bestemming van gediplomeerde schoolverlaters in het vervolgonderwijs en op de arbeidsmarkt. Daarbij kunnen twee componenten worden onderscheiden: een toepassingscomponent en een onderzoekscomponent. De toepassingscomponent richt zich op de zorg van individuele onderwijsinstellingen voor de onderwijskwaliteit en de afstemming van het onderwijs op de behoeften van de arbeidsmarkt. Daarvoor worden zogenaamde instellingsrapportages opgesteld waarin de onderwijsinstellingen informatie krijgen over hun eigen afgestudeerden, waar relevant afgezet tegen het landelijke beeld. Hiermee kunnen management, studierichtingsleiders en decanaat een indruk krijgen van het externe rendement van hun opleidingen.

1. Inclusief het individueel voorbereidend beroepsonderwijs (IVBO). 
De onderzoekscomponent van het schoolverlatersonderzoek, aangeduid als het Schoolverlatersinformatiesysteem (SIS), heeft als doel het analyseren van het doorstroompatroon van schoolverlaters naar vervolgonderwijs en het transitieproces van school naar werk. De resultaten hiervan worden onder meer gepubliceerd via landelijke rapportages. Hierin ligt het accent op (ontwikkelingen in) het intredeproces van schoolverlaters, de kansen op het vinden van werk, de kwaliteit van het werk en het keuzegedrag van schoolverlaters ten aanzien van mogelijke vervolgopleidingen en de kwaliteit van de aansluiting die daarbij wordt ondervonden.

\section{Opzet}

Zoals is aangegeven vormt een drietal schoolverlatersonderzoeken (RUBS, HBO-Monitor en WO-Monitor) de basis van SIS. Voor al deze schoolverlatersonderzoeken geldt dat onderwijsinstellingen zelf aangeven of zij met (een deel van) hun schoolverlaters of afgestudeerden willen deelnemen. De RUBS-enquête wordt bij de scholen aangeboden onder verantwoordelijkheid van het ROA. De HBO-Monitor wordt bij de hogescholen aangeboden onder auspiciën van de HBO-Raad. De WO-Monitor vindt in VSNU-verband plaats. Het ROA draagt zorg voor de uitvoering van de WO-Monitor voor tien universiteiten en heeft daarnaast de landelijke coördinatie. De Rijksuniversiteit Groningen, de Katholieke Universiteit Nijmegen en de Universiteit Twente voeren de enquête zelf uit. Ook de gegevens van deze 'lokale' uitvoerders zijn opgenomen in SIS. Binnen het agrarisch onderwijs worden de resultaten van de onderzoeken aangeboden door STOAS Onderzoek te Wageningen.

Door bovengenoemde werkwijze is er niet per se sprake van een aselecte steekproef. Met name bij de RUBS-enquête is de dekkingsgraad niet altijd even hoog (zie paragraaf 5). Mochten er 'witte vlekken' in de deelname aan RUBS ontstaan - zowel naar opleidingsrichting als regio dan wordt hier een aanvullende steekproef getrokken. In 2002 is dit niet nodig gebleken.

\section{Vragenlijsten}

Sinds het uitvoeringsjaar 1996 wordt het schoolverlatersonderzoek van het ROA uitgevoerd volgens een geïntegreerd model, waarbij één meetmoment en één kernvragenlijst wordt onderscheiden. In de periode september-december 2002 zijn ongeveer 95.000 schoolverlaters en afgestudeerden van het school-/studiejaar 2000/2001 benaderd met een schriftelijke vragenlijst. Dezelfde vragenlijst werd voor een groot aantal opleidingen ook via internet beschikbaar gesteld, zodat de schoolverlaters konden kiezen op welke manier ze de vragenlijst wilden invullen. Wanneer schoolverlaters na ruim een maand de vragenlijst nog niet hebben ingevuld, wordt een rappel verstuurd.

Hoewel de vragenlijsten in de kern gelijk zijn is er enige variatie aan vragen tussen de verschillende vragenlijsten. Hiermee wordt recht gedaan aan de verschillen die er tussen de diverse onderwijsniveaus of -sectoren bestaan. Binnen RUBS zijn aparte lijsten gebruikt voor de schoolverlaters van het (I)VBO en MAVO, HAVO/VWO, BOL en BBL. Bovendien zijn voor het agrarisch onderwijs op zowel (I)VBO- als BOL en BBL niveau specifieke vragenlijsten gebruikt. Binnen de HBO-Monitor is een aparte vragenlijst opgesteld voor de afgestudeerden van het 
landbouwonderwijs en het pedagogisch onderwijs. Daarnaast is onder de naam Kunsten-Monitor een specifieke vragenlijst opgesteld voor afgestudeerden van de HBO sector Taal en Cultuur. In het kader van de WO-Monitor zijn er, naast de standaard WO-vragenlijst, aparte vragenlijsten opgesteld voor het pedagogisch onderwijs en het agrarisch onderwijs (afgestudeerden van de Wageningen Universiteit).

Om een hogere respons te bereiken, is onder HBO-afgestudeerden van het kunstonderwijs die de schriftelijke vragenlijst niet hebben teruggestuurd (een deel van) de vragenlijst alsnog telefonisch afgenomen.

De vragenlijsten bestaan in de kern uit een viertal hoofdonderwerpen: algemeen (geslacht, leeftijd e.d.), onderwijsloopbaan, arbeidsmarktintrede en een thematisch gedeelte. ${ }^{2}$ Binnen de vragenlijsten voor het HAVO/VWO en het (I)VBO/MAVO ligt de nadruk op de doorstroom naar het vervolgonderwijs en de redenen van eventuele voortijdige uitval. Er wordt slechts in beperkte mate aandacht besteed aan de arbeidsmarktintrede van deze groep schoolverlaters. In de overige vragenlijsten ligt de nadruk juist op het transitieproces van school naar werk en wordt minder vergaand gevraagd over de doorstroom naar vervolgonderwijs.

In het uitvoeringsjaar 2002 is een deel van de vragenlijsten aanzienlijk gewijzigd ten opzichte van de vorige meetjaren. In paragraaf 6 wordt nader ingegaan op de redenen voor deze wijzigingen. De gevolgen van deze wijzigingen voor de schoolverlatersdata worden in paragraaf 7 besproken.

\section{Dataverwerking en weging}

Het versturen van alle vragenlijsten, het beschikbaar stellen van de vragenlijsten op internet, het verzorgen van de rappel en de verwerking van de binnengekomen vragenlijsten wordt uitgevoerd door DESAN Research Solutions te Amsterdam. Bij de verwerking worden de vragenlijsten direct ingevoerd door de respondent (bij de internetlijsten) of gescand (bij de schriftelijke lijsten), de open vragen gecodeerd (vervolgopleiding, beroep, bedrijfssector) en de eerste bestandscontroles en correcties uitgevoerd. Het ROA voert daarna een datacleaning uit op verwijzingsstructuur en op onderlinge consistenties. Vervolgens worden nieuwe, samengestelde variabelen aangemaakt en wordt het bestand gewogen, zodat op basis van de gegevens landelijk representatieve uitspraken kunnen worden gedaan. ${ }^{3}$

\section{Dataverwerking}

De vragenlijsten bevatten voor het merendeel gesloten antwoordcategorieën, waarbij de respondenten kunnen kiezen uit een aantal voorgelegde mogelijkheden. In een beperkt aantal gevallen dienen de schoolverlaters zelf een numerieke waarde in te vullen, bijvoorbeeld bij leeftijd, inkomen en aantal gewerkte uren. Bij enkele andere vragen wordt gebruik gemaakt van

2. Zie bijlage A voor een overzicht van het kerndeel van de vragenlijst.

3. Zie bijlage B voor een schematisch overzicht van het jaarlijkse schoolverlatersonderzoek. 
een volledig open vraagstelling, waarbij de schoolverlaters zelf het antwoord op de vraag moeten omschrijven. Dit is met name het geval bij vragen over:

- soort opleiding (voor- of vervolgopleiding);

- beroep;

- bedrijfssector;

- gemeente (woon- of werkgemeente).

Bij deze vragen worden de alfanumerieke antwoorden van de respondenten gecodeerd volgens vooraf opgestelde classificaties. Voor de opleidingsvragen wordt daarbij gebruik gemaakt van een speciaal voor dit doel door het ROA opgestelde opleidingsclassificatie, waarin alle in Nederland voorkomende (reguliere) opleidingen zijn opgenomen. ${ }^{4}$ Beroep en bedrijfssector worden gecodeerd volgens de Standaard Beroepen Classificatie 1992 (SBC '92) en de Standaard Bedrijfsindeling 1993 (SBI '93) van het CBS. Overigens zijn beide classificaties, waar relevant, door het toevoegen van een extra digit verder verbijzonderd. Gemeenten worden gecodeerd volgens de gemeentecodes die door het CBS in het meest recente Plaatsnamenregister worden gehanteerd.

$\mathrm{Na}$ de fase van data-entry worden de aldus verkregen ruwe gegevens door DESAN onderworpen aan een eerste kwaliteitscontrole. DESAN stelt het onderzoeksbestand samen en controleert op cruciale variabelen zoals uniek casenummer, schoolnummer, opleiding, respons, voltijd/deeltijd opleiding en diplomabezit. Deze variabelen worden onderling en met de variabele 'vragenlijst' op elkaar afgestemd. Bijvoorbeeld: komt een bepaalde (vol- of deeltijd) opleiding voor op een school, is voor een opleiding de juiste vragenlijst gehanteerd, is de vragenlijst grotendeels (met valide waarden) ingevuld, zijn de afgestudeerden ook gediplomeerd e.d. $\mathrm{Na}$ deze eerste controle geeft DESAN het onderzoeksbestand aan het ROA, waar vervolgens de volgende controles en correcties uitgevoerd worden:

1. Controle op variabelen met "anders-categorie": hierin wordt bekeken of er bij de vragen met een antwoordcategorie "anders, namelijk..." bepaalde overeenkomstige antwoorden kunnen worden onderscheiden zodat vervolgens eventuele nieuwe antwoordcategorieën worden aangemaakt of dat de "anders-categorie" teruggebracht kan worden naar een al bestaande antwoordcategorie (dit laatste is vaak het geval bij de vraag over de maatschappelijke positie van de respondent).

2. Doorvoeren van de verwijzingsstructuur: zijn er na een verwijzingsvraag 3 of meer vervolgvragen ingevuld dan wordt, indien nodig, het antwoord op de verwijzingsvraag aangepast zodat de verwijzing opgevolgd wordt. Zijn er minder dan 3 vervolgvragen na de verwijzing dan geldt dat alle vervolgvragen een geldig antwoord moeten hebben voordat een eventuele correctie op de desbetreffende verwijzingsvraag plaatsvindt. Zodoende garandeert de verwijzingsvraag altijd een juist aantal cases op de vervolgvragen. Verder wordt er een aparte code toegepast op vragen die wel beantwoord hadden moeten worden, maar die de

4. Daarbij is een rechtstreekse koppeling mogelijk met de Standaard Onderwijs Indeling (SOI) van het CBS. 
respondent niet heeft ingevuld (zogenaamde 'user-missing'). Vragen die de respondent door een eventuele verwijzing niet hoeft in te vullen blijven leeg (d.w.z op 'system-missing' staan).

3. Afronding cleaning: tot slot van de cleaning worden de cases die niet bruikbaar zijn uit het bestand verwijderd. Dit zijn onder andere de cases waarvan de afstudeerperiode niet correct is of cases waarvan meerdere cruciale basisvariabelen ontbreken.

$\mathrm{Na}$ de cleaning wordt het onderzoeksbestand uitgebreid met een aantal nieuwe samengestelde variabelen. Dit zijn variabelen die specifiek zijn gedefinieerd en/of op meerdere variabelen zijn gebaseerd (bijvoorbeeld de variabele 'beroepsbevolking').

\section{Weging}

De deelname van de scholen aan de schoolverlatersonderzoeken geschiedt zoals gezegd op vrijwillige basis. Hierdoor ontstaat er in de regel een ongelijke spreiding naar opleiding en regio. Ook naar andere kenmerken van de populatie kan er een niet-representatieve verdeling ontstaan. Zo is de respons bij vrouwen in het algemeen hoger dan bij mannen, waardoor vrouwen oververtegenwoordigd zijn in het onderzoeksbestand. Dergelijke omstandigheden leiden ertoe dat het onderzoeksbestand geen landelijke weergave is van de doelgroep. Om toch betrouwbare landelijke gegevens te kunnen presenteren, wordt een weging uitgevoerd op het bestand zoals dat na de dataverwerking is verkregen. Daarbij wordt een zodanige weging uitgevoerd dat de aantallen uiteindelijk corresponderen met de aantallen in de populatie.

Voor de weging wordt gebruik gemaakt van populatiegegevens die beschikbaar zijn op basis van de Integrale Leerlingtelling (ILT) (voor wat betreft het AVO, (I)VBO, BOL en BBL) en het Centraal Register Instellingen Hoger Onderwijs (CRIHO) (betreffende het HBO). Beide databestanden worden beheerd door het Ministerie van Onderwijs, Cultuur en Wetenschappen. De populatiegegevens van HBO Taal en Cultuur zijn echter niet gebaseerd op de CRIHO-data. Deze bleek niet volledig betrouwbaar voor deze sector. Als populatie is daarom het totale aantal uitgezette vragenlijsten per kunstopleiding gebruikt. Dit is mogelijk omdat van de opleidingen die in de steekproef zitten iedereen benaderd wordt. Ten aanzien van de schoolverlaters van de landbouwopleidingen wordt gebruik gemaakt van overeenkomstige gegevens beschikbaar gesteld door het Ministerie van Landbouw, Natuurbeheer en Visserij. Voor wat betreft de WOopleidingen ten slotte wordt geen weging, maar alleen een ophoging toegepast. De reden hiervoor is dat iedere afgestudeerde van het WO wordt benaderd en er dus geen sprake is van een steekproef.

De ILT 2000/2001 heeft per instelling en per opleiding gegevens beschikbaar over het aantal leerlingen per leerjaar en geslacht. Het CRIHO bevat per instelling en opleiding gegevens over het aantal diploma's, waarbij eveneens een onderverdeling naar geslacht is gemaakt. Er wordt op het niveau van opleiding $x$ regio $x$ geslacht een weegfactor bepaald die de verhouding aangeeft tussen het populatie-aantal en het aantal respondenten in het onderzoeksbestand. Bij de weging van $\mathrm{HBO}-o p l e i d i n g e n$ wordt bovendien een onderscheid gemaakt tussen voltijd- en deeltijdopleidingen. Voor een aantal opleidingen heeft voorafgaand aan de weging een clustering van opleidingen plaatsgevonden. Op dit hogere clusterniveau wordt vervolgens de 
weging uitgevoerd. Gewogen wordt op het niveau van opleiding x voltijd/deeltijd (alleen HBO) x regio $x$ geslacht. Indien de resulterende weegfactor groter is dan 3 maal de gemiddelde weegfactor en als bovendien de steekproef kleiner is dan 50 , dan wordt het kenmerk geslacht en indien noodzakelijk ook het kenmerk regio buiten beschouwing gelaten. In dat geval wordt gewogen op het niveau van opleiding $x$ voltijd/deeltijd (alleen HBO) $x$ regio, respectievelijk opleiding $x$ voltijd/deeltijd (alleen HBO). Tabel 4.1 geeft een overzicht van de aantallen schoolverlaters per opleidingssector vóór en ná de weging. Bij het HBO is daarbij een onderscheid gemaakt naar voltijd en deeltijd.

Tabel 4.1

Aantallen schoolverlaters per opleidingssector zowel voor weging als na weging

\begin{tabular}{|c|c|c|}
\hline Opleidingssector & $\begin{array}{l}\text { Ongewogen } \\
\text { aantal }\end{array}$ & $\begin{array}{c}\text { Gewogen } \\
\text { aantal }\end{array}$ \\
\hline AVO & 1.814 & 98.200 \\
\hline MAVO & 729 & 41.400 \\
\hline HAVO & 545 & 30.500 \\
\hline VWO & 540 & 26.300 \\
\hline VBO & 2.251 & 40.500 \\
\hline IVBO & 426 & 3.300 \\
\hline landbouw & 1.110 & 3.700 \\
\hline techniek & 360 & 15.200 \\
\hline economie & 129 & 8.000 \\
\hline gezondheidszorg & 226 & 10.300 \\
\hline BOL niveau $1 / 2$ & 844 & 13.400 \\
\hline landbouw & 112 & 400 \\
\hline techniek & 195 & 1.900 \\
\hline economie & 383 & 7.200 \\
\hline gezondheidszorg & 154 & 3.900 \\
\hline BOL niveau $3 / 4$ & 4.877 & 50.400 \\
\hline landbouw & 1.126 & 3.900 \\
\hline techniek & 1.300 & 11.100 \\
\hline economie & 1.018 & 17.100 \\
\hline gezondheidszorg & 671 & 7.600 \\
\hline gedrag en maatschappij & 762 & 10.600 \\
\hline BBL niveau $1 / 2$ & 1.284 & 20.800 \\
\hline landbouw & 278 & 1.800 \\
\hline techniek & 609 & 11.200 \\
\hline economie & 253 & 5.200 \\
\hline gezondheidszorg & 144 & 2.700 \\
\hline BBL niveau 3/4 & 1.329 & 18.100 \\
\hline landbouw & 192 & 1.000 \\
\hline techniek & 472 & 6.200 \\
\hline economie & 215 & 3.200 \\
\hline gezondheidszorg & 357 & 7.100 \\
\hline gedrag en maatschappij & 93 & 600 \\
\hline
\end{tabular}


Tabel 4.1 (vervolg)

Aantallen schoolverlaters per opleidingssector zowel voor weging als na weging

\begin{tabular}{lrr}
\hline Opleidingssector & $\begin{array}{c}\text { Ongewogen } \\
\text { aantal }\end{array}$ & $\begin{array}{c}\text { Gewogen } \\
\text { aantal }\end{array}$ \\
\hline HBO voltijd & 14.187 & \\
landbouw & 828 & 43.500 \\
onderwijs & 1.933 & 1.800 \\
techniek & 2.367 & 7.000 \\
economie & 4.324 & 9.000 \\
gezondheidszorg & 1.690 & 13.000 \\
gedrag en maatschappij & 2.014 & 4.300 \\
taal en cultuur & 1.031 & 6.100 \\
& & 2.200 \\
HBO deeltijd & 2.596 & \\
landbouw & 24 & 11.400 \\
onderwijs & 577 & 60 \\
techniek & 184 & 4.300 \\
economie & 388 & 800 \\
gezondheidszorg & 473 & 1.800 \\
gedrag en maatschappij & 863 & 1.500 \\
taal en cultuur & 87 & 2.900 \\
WO & & 200 \\
landbouw & 8.984 & \\
techniek & 275 & 20.000 \\
economie & 1.251 & 600 \\
gezondheidszorg & 1.274 & 2.800 \\
gedrag en maatschappij & 1.099 & 2.900 \\
taal en cultuur & 1.953 & 2.500 \\
recht en openbare orde & 1.030 & 4.400 \\
natuurwetenschappen & 1.208 & 2.300 \\
& 796 & 2.700 \\
& & 1.800 \\
& & \\
\hline
\end{tabular}

\section{Dekkingsgraad en respons}

De schoolverlaters die uiteindelijk in het onderzoeksbestand zijn opgenomen, vormen slechts een gedeelte van de gehele onderzoekspopulatie. Enerzijds worden niet álle personen uit de doelgroep benaderd en anderzijds reageert niet iedereen die wél is benaderd. De dekkingsgraad geeft een beeld van de omvang van het gedeelte van de populatie dat benaderd is. Het responspercentage geeft vervolgens aan welk deel van degenen die benaderd zijn daadwerkelijk heeft gereageerd.

\section{Dekkingsgraad}

Tabel 5.1 laat voor 2002 zien hoe groot de dekkingsgraad per onderwijssoort is. Uit de tabel blijkt dat er tussen de onderwijssoorten een groot verschil in dekkingsgraad bestaat. De dekkingsgraad bij zowel het AVO als het (I)VBO is laag (respectievelijk 3\% en 11\%). Voor het AVO betekent dit een lichte daling, voor het (I)VBO een lichte stijging in vergelijking met 2001. 
Zowel voor BOL als voor BBL geldt dat de dekkingsgraden van beide niveaus gedaald zijn ten opzichte van het jaar er voor. Van alle schoolverlaters uit het BOL en BBL wordt echter nog steeds één op de vijf gediplomeerden benaderd. Evenals de afgelopen jaren is bij het HBO ook dit jaar weer sprake van een zeer hoge deelname, de dekkingsgraad is hier $80 \%$. Wel is in vergelijking met het vorige meetjaar sprake van grotere verschillen tussen de $\mathrm{HBO}$ sectoren onderling. De cijfers van de sector HBO Taal en Cultuur kunnen niet worden weergegeven, omdat de populatiegegevens gelijk zijn aan het aantal uitgezette vragenlijsten (zie paragraaf 4). $\mathrm{Bij}$ het WO zijn de cijfers niet weergegeven omdat alle afgestudeerden van de door de overheid bekostigde instellingen worden benaderd.

Tabel 5.1

Dekkingsgraad per onderwijssoort

Onderwijssoort

Benaderd
aantal $\quad \begin{gathered}\text { Dekking } \\ \%\end{gathered}$

AVO
MAVO
HAVO
VWO
VBO
IVBO
landbouw
techniek
economie
gezondheidszorg
BOL niveau 1/2
landbouw
techniek
economie
gezondheidszorg
BOL niveau 3/4
landbouw
techniek
economie
gezondheidszorg
gedrag en maatschappij

40510

$B B L$ niveau $1 / 2$

$10.562 \quad 21$

$2.433 \quad 62$

$3.067 \quad 28$

$2.497 \quad 15$

$1.206 \quad 16$

1.359

landbouw

$4.066 \quad 20$

techniek

$939-52$

economie

gezondheidszorg

405

$B B L$ niveau $3 / 4$

$3.414 \quad 19$

landbouw

$451 \quad 45$

techniek

$1.366 \quad 22$

economie

64920

gezondheidszorg

774

gedrag en maatschappij

$174 \quad 29$


Tabel 5.1 (vervolg)

Dekkingsgraad per onderwijssoort

\begin{tabular}{lcc}
\hline Onderwijssoort & $\begin{array}{c}\text { Benaderd } \\
\text { aantal }\end{array}$ & $\begin{array}{c}\text { Dekking } \\
\%\end{array}$ \\
\hline$H B O^{5}$ & 38.685 & 80 \\
landbouw & 1.816 & 98 \\
onderwijs & 6.591 & 58 \\
techniek & 7.229 & 74 \\
economie & 11.911 & 80 \\
gezondheidszorg & 4.479 & 67 \\
gedrag en maatschappij & 6.659 & \\
\hline
\end{tabular}

Respons

Zoals uit tabel 5.2 blijkt is de respons ${ }^{6}$ het hoogst bij de schoolverlaters van het AVO (54\%) en het VBO (53\%). Ten opzichte van het vorige meetjaar is dit een aanzienlijke verbetering hetgeen veroorzaakt wordt door de veel kortere vragenlijsten (zie ook paragraaf 6). Evenals voorgaande jaren is de respons van BBL niveau 1/2 (32\%) het laagst.

Wat verder opvalt is dat er binnen iedere onderwijssoort sprake is van een vrij grote spreiding in de responspercentages. De afgelopen jaren is er sprake van een dalende lijn in de responspercentages. Deze daling heeft zich in 2002 alleen nog bij het HBO doorgezet. De respons ligt hier nu op 42\%. De dalende trend binnen het WO lijkt zich enigszins te stabiliseren.

Tabel 5.2

Responspercentage per opleidingssector

\begin{tabular}{lc}
\hline Opleidingssector & $\%$ \\
\hline AVO & 54 \\
MAVO & 51 \\
HAVO & 53 \\
VWO & 59 \\
VBO & 53 \\
IVBO & 46 \\
landbouw & 60 \\
techniek & 46 \\
economie & 43 \\
gezondheidszorg & 59 \\
BOL niveau 1/2 & 35 \\
landbouw & 32 \\
techniek & 34 \\
economie & 35 \\
gezondheidszorg & 39
\end{tabular}

5. Exclusief HBO Taal en Cultuur.

6. Voor de berekeningswijze van de respons zie Willems en Van der Linden (1998). 
Tabel 5.2 (vervolg)

Responspercentage per opleidingssector

Opleidingssector

$\%$

$\begin{array}{lr}\text { BOL niveau 3/4 } & 47 \\ \text { landbouw } & 46 \\ \text { techniek } & 45 \\ \text { economie } & 41 \\ \text { gezondheidszorg } & 56 \\ \text { gedrag en maatschappij } & 56 \\ \text { BBL niveau 1/2 } & 32 \\ \text { landbouw } & 30 \\ \text { techniek } & 31 \\ \text { economie } & 35 \\ \text { gezondheidszorg } & 36 \\ \text { BBL niveau 3/4 } & 39 \\ \text { landbouw } & 43 \\ \text { techniek } & 35 \\ \text { economie } & 33 \\ \text { gezondheidszorg } & 46 \\ \text { gedrag en maatschappij } & 53 \\ \text { HBO } & 42 \\ \text { landbouw } & 48 \\ \text { onderwijs } & 40 \\ \text { techniek } & 37 \\ \text { economie } & 41 \\ \text { gezondheidszorg } & 50 \\ \text { gedrag en maatschappij } & 45 \\ \text { taal en cultuur } & 33 \\ \text { WO } & 46 \\ \text { landbouw } & 57 \\ \text { techniek } & 54 \\ \text { economie } & 38 \\ \text { gezondheidszorg } & 46 \\ \text { gedrag en maatschappij } & 50 \\ \text { taal en cultuur } & 47 \\ \text { recht en openbare orde } & 38 \\ \text { natuurwetenschappen } & 52\end{array}$

Door middel van een responsanalyse is geprobeerd een beter inzicht te krijgen in de factoren die van invloed zijn op de respons. Aangezien er (per definitie) vrij weinig gegevens bekend zijn over de schoolverlaters die niet gerespondeerd hebben, is de responsanalyse noodzakelijkerwijs beperkt. Er is informatie aanwezig over drie factoren die mogelijk invloed hebben op de respons. Ten eerste is informatie over de gevolgde opleiding van de aangeschreven schoolverlaters aanwezig. Ten tweede is de wijze van verzending van de vragenlijsten bekend. De vragenlijsten kunnen enerzijds centraal door DESAN aan de afgestudeerden worden toegestuurd; anderzijds kunnen de onderwijsinstellingen de vragenlijsten zelf verzenden. Dit laatste noemen we decentrale verzending. Ten derde is de regioverdeling in de steekproef bekend. 
Wellicht geldt dat het responspercentage in de ene regio hoger ligt dan in de andere. Wanneer een bepaalde regio in de loop der jaren een steeds belangrijkere rol is gaan vervullen in de steekproef en als de respons tussen regio's inderdaad verschilt, dan kan dit een verklaring zijn voor veranderingen in de totale respons. Een soortgelijke situatie kan natuurlijk ook gelden voor het opleidingsniveau dat schoolverlaters hebben voltooid. Met behulp van een logistische regressie-analyse is nagegaan wat de invloed is van deze drie factoren op de respons. De resultaten van deze analyse staan weergegeven in tabel 5.3.

Tabel 5.3

De invloed van onderwijssoort, regio en wijze van verzending op respons: logit effecten

Onafhankelijke variabelen

Parameter

Standaardfout

Constante

$-0,09^{* *} \quad 0,02$

Onderwijssoort:

AVO

VBO

BOL $1 / 2$

$0,30^{* *} \quad 0,04$

BOL $3 / 4$

$0,30^{* *}$

$-0,48^{* *}$

0,03

BOL $3 / 4$

0,04

0,05

BBL $3 / 4$

$-0,62^{* \star}$

0,03

$-0,31^{* *}$

0,04

$\mathrm{HBO}$

WO

$-0,18^{* *}$

0,04

referentiecategorie

Regio:

Noord

$-0,06^{*} \quad 0,03$

Oost

$-0,04$

0,02

West

$-0,13^{* *}$

0,02

Zuid

referentiecategorie

Decentrale verzending

$0,05^{*}$

0,02

$N=88.832$

* significant op 5\%-niveau

** significant op 1\%-niveau

De analyse toont dat, gecorrigeerd voor regio en wijze van verzending, schoolverlaters van het AVO en het VBO het vaakst responderen. De schoolverlaters van de kortere beroepsopleidingen responderen relatief gezien het minst vaak: de respons van BBL niveau $1 / 2$ is het laagst, gevolgd door BOL niveau 1/2. Deze bevindingen zijn in overeenstemming met de gegevens uit tabel 5.2. Verder blijkt dat de respons geografisch ongelijkmatig verdeeld is. Met name in het Westen is de respons laag; in het Zuiden van het land ligt de respons relatief gezien het hoogst.

Daarnaast blijkt dat decentraal verzenden een hogere respons oplevert ten opzichte van centrale verzending van vragenlijsten. Dit laatste punt kan veroorzaakt worden door verschillende factoren. Zo kan het zijn dat respondenten zich meer betrokken voelen bij de enquête indien ze door de eigen school worden benaderd. Het is echter ook mogelijk dat de 
onderwijsinstellingen die de enquête zelf verzenden over betere adressenbestanden beschikken dan de instellingen die dit uitbesteden. Bij deze laatste groep instellingen zal een groter deel van de verstuurde vragenlijsten de schoolverlater nooit bereiken hetgeen uiteraard een lagere respons tot gevolg heeft.

Tijdens de dataverzameling bleek dat bij het $\mathrm{HBO}$ en het WO ook dit meetjaar de respons weer iets achter bleef bij de respons van het vorige meetjaar. Bij een nadere analyse van deze cijfers na sluiting van de responsperiode bleek dat dit, behalve met de al jaren toenemende trend van 'enquêtemoeheid' onder de Nederlandse bevolking, met name te maken heeft met de mindere kwaliteit van de aangeleverde adressenbestanden. Dit wordt veroorzaakt door de verminderde aandacht voor het alumnibeleid door de onderwijsinstellingen.

Daarnaast speelt met name in het WO het stijgend aantal buitenlandse studenten een rol. Deze, voor het merendeel niet-Nederlands sprekende groep afgestudeerden wordt op dit moment nog benaderd met een Nederlandstalige brief en een Nederlandstalig enquêteformulier. Van deze groep zal vrijwel niemand responderen. Er is afgesproken dat voor meetjaar 2003 de instellingen er nog eens expliciet op gewezen dienen te worden dat het onderhouden en het aanleveren van een actueel en correct adressen-/alumnibestand van grote invloed is op de respons. Daarnaast zal er op internet een Engelse versie van de reguliere HBO- en WO vragenlijst beschikbaar komen voor buitenlandse studenten. In de met de enquête meeverzonden brieven zal een korte Engelstalige paragraaf worden opgenomen waarin naar deze mogelijkheid wordt verwezen.

Tabel 5.4 geeft tot slot een overzicht van de aantallen in 2002 uitgezette en teruggestuurde vragenlijsten. Dit overzicht geeft bovendien enkele redenen weer waarom sommige teruggestuurde vragenlijsten niet geschikt zijn voor verwerking. De belangrijkste reden hiervoor is het ontbreken van een juist adres. 


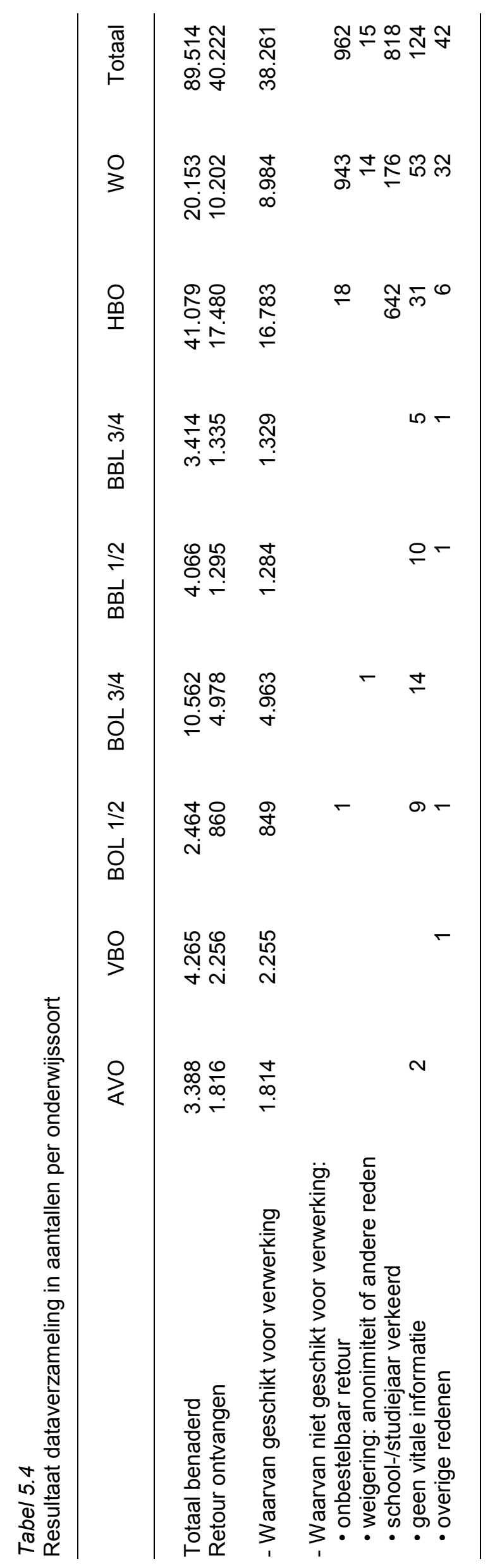




\section{Invoering nieuwe vragenlijsten}

In het uitvoeringsjaar 2002 is er bij RUBS integraal gebruik gemaakt van een sterk verkorte en vernieuwde vragenlijst. Binnen de HBO-Monitor en de WO-Monitor is zo'n 6\% van de steekproef benaderd met een nieuwe variant van de vragenlijsten. Onderwijsinstellingen (bijvoorbeeld de Universiteit van Amsterdam) en onderwijssectoren (bijvoorbeeld het hoger agrarisch onderwijs) die reeds over een eigen variant van de vragenlijst beschikten zijn om organisatorische redenen niet in deze steekproef opgenomen.

In het voorjaar van 2002 heeft een herziening van de kernvragenlijst plaatsgevonden. Er was een aantal redenen om tot herziening van de vragenlijsten over te gaan:

- Voor de berekening van sommige kernindicatoren waren onnodig veel vragen nodig. Bij de start van de ROA-schoolverlatersonderzoeken werd aansluiting gezocht bij officiële definities van bijvoorbeeld de beroepsbevolking. In enkele gevallen legde dit beslag op een aanzienlijk deel van de vragenlijsten en leidde dit incidenteel tot voor respondenten moeilijk te 'plaatsen' vragen.

De opgedane ervaringen van de afgelopen jaren hebben geleerd dat het niet altijd wenselijk en noodzakelijk is om deze officiële definities volledig te volgen.

- In de loop der jaren hebben sommige, in eerste instantie éénmalige, vragen het predikaat 'standaard-/kernvraag' gekregen terwijl ze dit feitelijk nooit zijn geweest of in ieder geval niet hoefden te blijven.

- In de vragenlijsten oude stijl werd regelmatig gebruik gemaakt van vragen in de vorm van uitspraken waarbij de respondent kon aangeven in hoeverre hij/zij het met deze uitspraken eens dan wel oneens was. Deze vraagvorm geeft antwoord op de vraag in hoeverre de respondent het met een bepaalde uitspraak eens is en niet op de vraag in welke mate de uitspraak van toepassing is op de respondent. Voor het arbeidsmarktonderzoek is het van belang een antwoord te krijgen op deze tweede vraag en was een herziening dus noodzakelijk.

- Een aantal van de vragen werd heel eenzijdig ingevuld waardoor de meeste antwoorden zich in twee categorieën concentreerden (dit speelt met name een rol bij de competentievragen). Dit heeft tot gevolg dat er bij deze vragen weinig differentiatie tussen respondenten is en de onderzoeksmogelijkheden beperkt zijn.

- Door een zorgelijke daling in de responscijfers was het met name voor RUBS nodig om iets aan de non-respons te doen. Aangezien één van de belangrijkste redenen voor het niet invullen van de vragenlijsten te maken heeft met de lengte van de enquête is besloten om deze aanzienlijk in te korten.

- Voor het blijven behouden van een breed maatschappelijk draagvlak voor de ROA schoolverlatersonderzoeken is het van belang dat er gewerkt wordt met goed uitziende en inhoudelijk actuele vragenlijsten. Dit betekent dat er om de paar jaar ook grondig gekeken moet worden naar zaken als taalgebruik en lay-out. 
Het vragenblok ten behoeve van het meten van de competenties van afgestudeerden was aan herziening toe. Ten eerste omdat de wetenschappelijke inzichten met betrekking tot dit onderzoeksgebied in de loop der jaren veranderd zijn. Ten tweede is door de invoering van het nieuwe accreditatiesysteem in het hoger onderwijs het belang van een goede en actuele competentiemeting nog meer noodzakelijk geworden dan voorheen.7

In de gebruikte proeflijsten voor het HBO en het WO heeft dit tot een aantal wijzigingen geleid. Competenties worden opgevat als vereisten voor effectieve handelingen. Om de relatie tussen competenties en handelen duidelijk te maken is er gekozen voor een meer actieve formulering van de items in de competentielijst (daar waar mogelijk). Zo is er bijvoorbeeld in de oude vragenlijst sprake van het aspect 'communicatieve vaardigheden', in de vernieuwde lijst is dit aspect 'aan anderen duidelijk maken wat $u$ bedoelt'. Voor respondenten zal deze laatste formulering concreter zijn dan de eerste hetgeen de juistheid en de vergelijkbaarheid van de antwoorden ten goede komt.

In de oude opzet werd de afgestudeerden gevraagd de lijst van aspecten op een drietal punten te beoordelen. De beoordelingen 'gebruik' en 'vereist niveau' hadden echter alleen betrekking op aspecten (competenties) die in het werk gebruikt werden. Bij de nieuwe opzet is er rekening mee gehouden dat afgestudeerden ook competenties kunnen hebben verkregen die niet gebruikt worden in de huidige functie. Deze niet gebruikte competenties kunnen echter wel door de opleiding zijn aangeleerd en in toekomstige functies c.q andere omstandigheden wel relevant worden. Met name voor onderwijsinstellingen is het van belang dat ook deze competenties gemeten worden.

Een ander nadeel van de competentievragen oude stijl zijn de antwoordcategorieën. De gekozen 5- en 4-puntsschaal leverde in het verleden weinig variantie in de antwoorden op. Met de introductie van rapportcijfers $(1 \mathrm{t} / \mathrm{m} \mathrm{10})$ is geprobeerd hier iets aan te doen. Het is gebleken dat door de verschillende referentiekaders van respondenten deze methode echter relatief gevoelig is voor subjectiviteit. Om hier, eventueel, voor te kunnen corrigeren is een vraag opgenomen over hoe men zichzelf qua niveau inschat ten opzichte van de andere afgestudeerden van de eigen opleiding. Er is eveneens een vraag opgenomen over hoe men zichzelf qua niveau inschat ten opzichte van alle afgestudeerden in het HBO c.q WO. Indien er geen sprake is van subjectiviteit en iedere respondent zijn eigen - en het niveau van anderen goed kan inschatten moet deze vragen over alle respondenten samen een gemiddeld antwoord (0) opleveren. Bij de eerste vraag zou tevens per opleiding het gemiddelde gelijk aan 0 moeten zijn. Afwijkingen hiervan geven een beeld van de mate waarin afgestudeerden hun capaciteiten te hoog of te laag inschatten.

In Bijlage C staat het volledige competentievragenblok van de reguliere vragenlijst en van de proeflijst.

7. Zie ook dr. J. Allen, dr. R. van der Velden en drs. G. Ramaekers, Measuring competencies of higher education graduates, ROA, 2003. 


\section{Evaluatie nieuwe vragenlijsten}

Respons

Een van de doelstellingen van de invoering van de nieuwe, kortere vragenlijsten was het verhogen van de respons. De integrale invoering van de nieuwe lijst hebben bij het RUBS onderzoek inderdaad geleid tot een aanzienlijke verhoging van de responscijfers (zie tabel 7.1).

Tabel 7.1

Responscijfers RUBS 2002 t.o.v vorig meetjaar

\begin{tabular}{lcc}
\hline Opleidingstype & Respons & Respons \\
& $\begin{array}{c}\text { SIS2001 } \\
\%\end{array}$ & $\%$ \\
& & \\
\hline HAVO/VWO & & 54 \\
(I)VBO/MAVO & 51 & 53 \\
BOL 1/2 & 35 & 35 \\
BOL 3/4 & 26 & 47 \\
BBL 1/2 & 39 & 32 \\
BBL 3/4 & 24 & 39 \\
\end{tabular}

Uit de tabel blijkt dat met name onder de (I)VBO/MAVO schoolverlaters het effect van een kortere vragenlijst aanzienlijk is. De respons is hier met $18 \%$ gestegen. Bij de overige onderwijstypen is sprake van een responsstijging van $8 \%$ of $9 \%$. Het responseffect van de nieuwe vragenlijst is het laagst bij de schoolverlaters van het AVO namelijk $3 \%$. Omdat de respons van deze groep altijd al bijzonder hoog is geweest werden hier op voorhand ook geen grote responsstijgingen verwacht. Bovendien was de vragenlijst hier al een stuk korter (geen arbeidsmarktvragen bijvoorbeeld).

Binnen het hoger onderwijs is er slechts onder een beperkt deel van de respondenten gebruik gemaakt van de nieuwe vragenlijst. Het is gebleken dat deze kortere vragenlijst hier niet heeft geleid tot een hogere respons. De nieuwe vragenlijst kende zelfs een lagere respons dan de oude, langere vragenlijsten. Bij het HBO bleef de respons van de nieuwe lijsten $1 \%$ onder de respons van de reguliere lijst. Bij het WO was dit zelfs $4 \%$. Omdat er tussen de proeflijst en de reguliere lijst geen verschillen waren met betrekking tot het tijdstip en de wijze van aanbieden lijkt het er op dat binnen het hoger onderwijs de lengte van de reguliere vragenlijsten niet de oorzaak is van de dalende responscijfers van de afgelopen jaren.

\section{Veranderingen in item non respons}

Naast een algemeen responseffect kunnen veranderingen van de vragenlijsten ook gevolgen hebben voor de item non respons. Dit betekent dat respondenten de vragenlijst wel invullen en terugsturen maar specifieke vragen vaker niet, of juist wel vaker ingevuld hebben dan voorheen. Dit omdat de vraagstelling en/of de antwoordcategorieën minder duidelijk dan wel duidelijker gesteld zijn. Er is bij een aantal kernvariabelen nagegaan in hoeverre er sprake is van een 
toename van de item non respons. Daarbij is voor zowel het HBO als het WO gekeken naar verschillen in item non respons tussen de reguliere vragenlijst en de vernieuwde vragenlijst. In tabel 7.2 staan de percentages item non respons van de reguliere vragenlijst en de vernieuwde lijst van enkele kernvariabelen, uitgesplitst naar HBO en WO.

Tabel 7.2

Item non respons kernvariabelen, reguliere en vernieuwde vragenlijsten, HBO en WO

\begin{tabular}{|c|c|c|c|c|}
\hline & $\begin{array}{c}\mathrm{H} \\
\text { oud } \\
\%\end{array}$ & $\begin{array}{l}\text { O } \\
\text { nieuw } \\
\%\end{array}$ & $\begin{array}{c}\mathrm{V} \\
\text { oud } \\
\%\end{array}$ & $\begin{array}{c}\text { nieuw } \\
\%\end{array}$ \\
\hline Beroepsbevolking & 12,2 & 13,9 & 4,8 & 4,1 \\
\hline Minimaal eigen niveau & 1,2 & $3,6^{*}$ & 0,8 & 0,9 \\
\hline Eigen/verwante richting & 0,6 & $2,1^{*}$ & 0,6 & $2,8^{*}$ \\
\hline Tijdelijke aanstelling & 3,1 & $7,1^{*}$ & 3,3 & $6,6^{*}$ \\
\hline Arbeidsuren & 0,4 & 0,2 & 0,0 & 0,0 \\
\hline Inkomen & 10,9 & 10,9 & 8,4 & 8,2 \\
\hline
\end{tabular}

${ }^{*}=$ significant op $1 \%$-niveau

Bij het $\mathrm{HBO}$ is er een significant hogere item non respons bij de onderdelen 'functie op minimaal eigen niveau' en 'functie binnen eigen of verwante richting' en 'tijdelijke aanstelling'. Bij de WO vragenlijsten is dit het geval bij de onderdelen 'functie binnen eigen of verwante richting' en 'tijdelijke aanstelling'. Alhoewel de beide varianten van de vragen niet veel van elkaar verschillen heeft blijkbaar iets bij de nieuwe vragenlijst geleid tot een hogere item non respons op genoemde onderdelen. Bij het opstellen van de vragenlijsten voor meetjaar 2003 wordt geprobeerd hiermee rekening te houden.

\section{Wijzigingen}

Bij een aantal vragen is de vraagstelling enigszins veranderd of is de vraag in zijn geheel niet meer gesteld. De belangrijkste wijzigingen hebben betrekking op de volgende onderdelen:

Gevolgde opleiding; de gevolgde opleiding wordt niet meer voorgedrukt op de vragenlijst. Dit betekent dat er niet om een bevestiging wordt gevraagd maar dat er gevraagd wordt naar de naam van de gevolgde opleiding. Omdat deze informatie ook al door de onderwijsinstelling aangeleverd wordt is de item non-respons op deze vraag geen probleem.

Gevolgde vooropleiding; er wordt niet meer naar de hoogste vooropleiding gevraagd maar naar alle eerder behaalde diploma's. Dit betekent dat de nieuwe variabele 'hoogste vooropleiding' (n_vohh) niet meer direct afgeleid kan worden, maar berekend moet worden. Alhoewel de nieuwe vraagstelling meer informatie oplevert is er ook een, niet voorzien, nadeel aan verbonden: het blijk namelijk dat een aanzienlijk deel van de BOL en BBL respondenten dit jaar aangeven al eerder een BOL dan wel BBL diploma te hebben behaald. Het gaat hier echter om het eerder behaalde diploma van BOL /BBL niveau 1 (bij de uitstroom van niveau 2) en BOL/BBL niveau 3 (bij de uitstroom van niveau 4) van dezelfde opleiding. Bij de berekening van de variabele n_vohh is hier rekening mee gehouden. 
Vervolgopleiding; in aanvulling op de vraag over de begonnen vervolgopleiding vlak na het verlaten van de gevolgde opleiding wordt ook gevraagd of de respondent op dit moment een vervolgopleiding volgt.

Zoekgedrag (ander) betaald werk en werkloosheid; een aantal vragen is niet meer gesteld. Zo wordt er niet meer gevraagd of men de afgelopen 4 weken iets gedaan heeft om aan (ander) betaald werk te komen. Daarnaast wordt niet meer naar de directe beschikbaarheid en de redenen van een eventuele vertraagde beschikbaarheid gevraagd. De vraag over het gewenst aantal arbeidsuren is eveneens vervallen. Dit betekent dat een belangrijke indicator, namelijk de werkzame/werkloze beroepsbevolking (variabelen n_berbv1 en n_berbv2) binnen de schoolverlatersonderzoeken een iets andere invulling gekregen heeft en hiermee afwijkt van de vroeger gehanteerde CBS definitie van werkloosheid. lemand die minder dan 12 uur werkt of geen werk heeft en wel op zoek is naar werk behoort tot de werkloze beroepsbevolking ongeacht het zoekgedrag van de afgelopen vier weken en de mate van beschikbaarheid of het gewenst aantal arbeidsuren. Uit een analyse van de werkloosheidscijfers volgens de oude en de nieuwe definitie per onderwijssector blijkt dat de nieuwe werkloosheidsdefinitie tot gelijke of in enkele gevallen iets hogere percentages heeft geleid. De afwijkingen zijn maximaal $1 \%$ en komen met name voor in periodes van hoge werkloosheid. Door het wegvallen van het gewenst aantal arbeidsuren is daarnaast niet meer te bepalen of iemand vrijwillig of niet vrijwillig een deeltijdaanstelling heeft (n_ovda en n_vvda).

Beloning; de vraag over het inkomen van afgestudeerden is sterk vereenvoudigd. Er wordt ten eerste niet meer de mogelijkheid geboden om het inkomen per maand, vier weken of per week in te vullen. Respondenten geven aan wat hun bruto inkomen per maand is. Ten tweede is de uitgebreide toelichting bij de vraag sterk ingekort tot 'exclusief overuren, inclusief toeslagen'. Deze beide veranderingen hebben niet geleid tot hogere of lagere gemiddelde maandinkomens bij het HBO en WO.

Op de proeflijsten in het hoger onderwijs is de volledige toelichting bij de beloningsvraag weg gelaten. Hier wordt wel een onderscheid gemaakt tussen inkomsten uit contracturen uit de hoofdfunctie en inkomsten uit overuren uit de hoofdfunctie. Daarnaast wordt eveneens gevraagd naar eventuele inkomsten uit andere banen dan de hoofdfunctie.

Arbeidsuren; de toelichting bij de vraag over het aantal arbeidsuren volgens contract is aanzienlijk ingekort tot '(adv, overuren, uren op school (bij BBL, HBO duaal) niet meetellen)'.

Op de proeflijsten in het hoger onderwijs wordt in de toelichting, alleen voor leraren, erop gewezen dat 1 leseenheid 1,5 arbeidsuur is. Hier wordt ook weer onderscheid gemaakt tussen reguliere uren op basis van het contract, overuren en uren in andere banen.

Flexibele arbeidsrelatie ( $n \_h f l e x$ ); bij de vraag over het soort aanstelling wordt bij tijdelijke aanstellingen niet meer naar de duur (in maanden) van de aanstelling gevraagd. In vergelijking met voorgaande meetjaren heeft dit tot een aanzienlijk hoger percentage werkenden met een 'flexibele arbeidsrelatie' geleid. In het verleden hadden respondenten met een tijdelijke aanstelling van 12 maanden of meer geen flexibele arbeidsrelatie. Met de nieuwe vraagstelling 
behoort iedereen met een tijdelijke aanstelling, ongeacht de duur, tot de groep werkenden met een flexibele aanstelling.

\section{Veranderingen in de kernindicatoren}

Een belangrijke voorwaarde voor handhaving, en in het hoger onderwijs verdere invoering, van de nieuwe vragenlijsten is de betrouwbaarheid en continuïteit van de belangrijkste arbeidsmarktindicatoren van de schoolverlatersdata. Er mogen met andere woorden geen trendbreuken in de data ontstaan als gevolg van de nieuwe vragenlijsten. Er is wederom bij een aantal kernvariabelen nagegaan in hoeverre er sprake is van afwijkingen tussen de groep afgestudeerden met een reguliere vragenlijst en afgestudeerden met de vernieuwde vragenlijst. Dit is voor zowel het HBO als het WO gedaan. In tabel 7.3 staan hiervan de resultaten.

Tabel 7.3

Kernvariabelen, verschillen tussen reguliere en vernieuwde vragenlijsten, HBO en WO

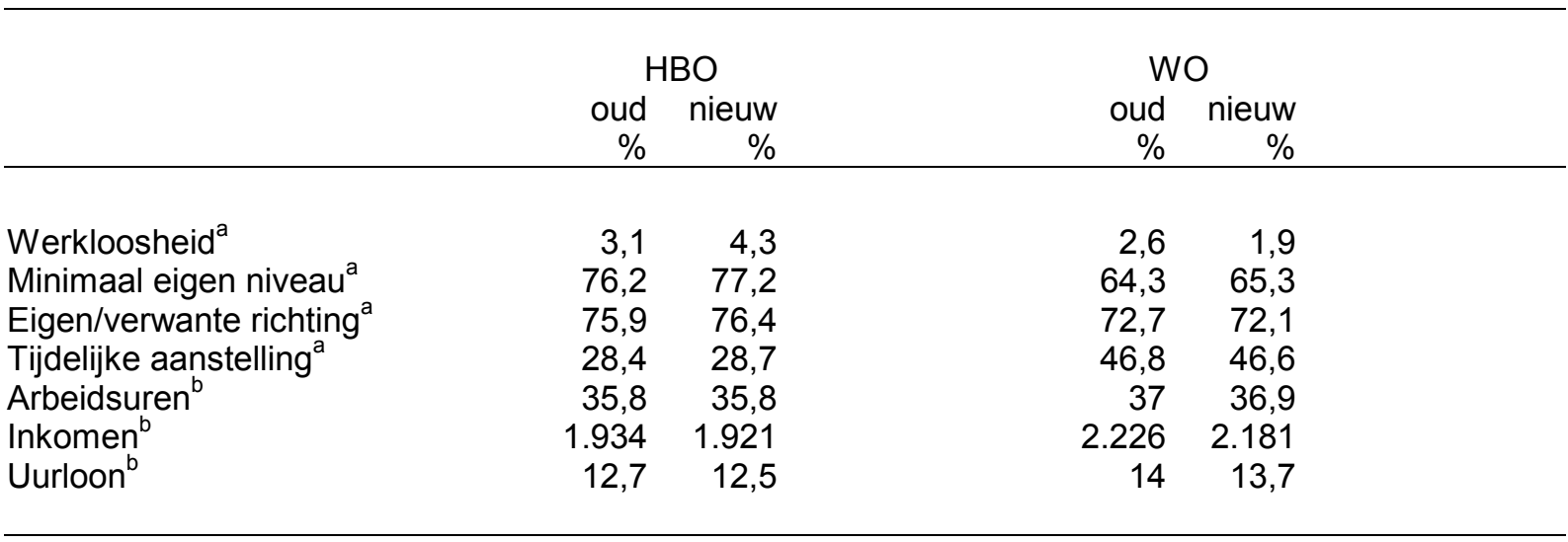

$\mathrm{a}=$ percentages

$\mathrm{b}=$ gemiddelden

Uit de tabel blijkt dat er weinig verschillen zijn tussen de beide vragenlijstvarianten voor zover het de onderzochte kernindicatoren betreft; zowel bij het HBO als het WO waren er geen significante verschillen. Dit betekent dat de doorgevoerde veranderingen (in de kern) van de vragenlijsten niet hebben geleid tot andere uitkomsten en/of trendbreuken. Het merendeel van de vernieuwde vragen zal dan ook in het komenden meetjaar (SIS 2003) weer op dezelfde wijze worden gesteld.

\section{Veranderingen van de competentievragen}

Een analyse van de gegevens verkregen op basis van het nieuwe competentievragenblok toont dat de item non-respons van de nieuwe vragen iets hoger is dan de item non-respons van de vragen volgens de oude opzet. Wellicht vergt het moeten toekennen van een rapportcijfer meer van respondenten dan het omcirkelen van een cijfer tussen 1 en 5 . Daarnaast was het nieuwe competentievragenblok aanzienlijk langer (24 aspecten in plaats van 14) dan het reguliere vragenblok. Echter ook in vergelijking met lijsten van 29 items, die in het verleden gebruikt zijn is het item non-respons van het nieuwe competentieblok hoog. 
Een van de redenen voor het veranderen van de competentievragen was dat de antwoorden verkregen met het reguliere vragenblok weinig variantie vertoonden. De introductie van een $10-$ puntsschaal (rapportcijfer tussen 1 en 10) heeft echter niet geleid tot een verbetering op dit vlak. De reden hiervoor is dat het overgrote deel van de respondenten zich bij ieder aspect een 6 of hoger toekent. Men geeft zichzelf met andere woorden niet graag een onvoldoende.

Naar aanleiding van bovenstaande bevindingen zijn voor het meetjaar 2003 de competentievragen op de volgende twee punten aangepast:

- de 10 puntsschaal (rapportcijfer) is teruggebracht naar een 5 puntsschaal waarbij de grenswaarden variëren van 'matig' tot 'uitmuntend';

- de volgorde van de vragen/kolommen is aangepast; respondenten dienen nu eerst het vereist niveau voor de huidige functie in te vullen en daarna het eigen niveau.

\section{Besluit}

In dit werkdocument is de methodiek beschreven van het Schoolverlatersinformatiesysteem (SIS) dat door het ROA in 2002 is uitgevoerd. Naast een overzicht van de opzet van dit onderzoek, de gehanteerde classificaties en de uitgevoerde controles en toegepaste correcties op het databestand, is vooral ingegaan op de dekkingsgraad, de respons en op de (gedeeltelijke) invoering van de vragenlijsten nieuwe stijl.

De dekkingsgraad is het laagst bij het AVO (3\%) en het VBO (11\%). Bij het HBO is de dekkingsgraad evenals voorgaande jaren bijzonder hoog namelijk $80 \%$.

De respons is het hoogst onder schoolverlaters van het AVO (54\%). Ook het VBO heeft een vergelijkbaar hoog responspercentage. De respons onder de afgestudeerden van BBL niveau $1 / 2$ is het laagst namelijk $32 \%$. Daarnaast komt uit de responsanalyse naar voren dat in het Westen van het land het minst vaak wordt gerespondeerd. Het centraal verzenden van de vragenlijsten heeft eveneens een licht negatief effect op de respons.

Voor een aanzienlijk deel van de afgestudeerden is in 2002 een vernieuwde vragenlijst gebruikt. Dit omdat om verschillende redenen enkele vragen niet meer als 'kernvraag' betiteld hoefden te worden. Daarnaast waren sommige vragen aan een herziening toe in verband met een noodzakelijke verbetering van de vraag (en antwoordmogelijkheden). De dalende trend in de responscijfers maakt ten slotte een inkorting van de vragenlijsten noodzakelijk (met name bij RUBS).

Binnen het RUBS onderzoek hebben de vragenlijsten geleid tot een aanzienlijke stijging van de respons. Op de kernvragen 'werkzaam in eigen of verwante richting' en 'tijdelijke aanstelling' hebben de nieuwe vragenlijsten in het hoger onderwijs tot een iets hogere item non respons geleid. Daarnaast heeft een vergelijking van enkele kernindicatoren laten zien dat er geen significant verschil bestaat tussen de kernindicatoren op basis van de nieuwe vragenlijst en de kernindicatoren op basis van de oude vragenlijst. 


\section{Literatuur}

Allen, J.P., Ramaekers, G. (2003), Een conceptueel kader voor het meten van competenties van hoger opgeleiden, ROA, Maastricht.

Willems, E.J.T.A., A.S.R. van der Linden (1998), Methodiek schoolverlatersinformatiesysteem 1996, ROAW-1998/1, Maastricht.

Nijdam, B., H. van Buuren (1995), Statistiek voor de sociale wetenschappen, Samson Bedrijfsinformatie Alphen aan den Rijn. 



\section{Bijlage A: Kernvragenlijst}

Tabel A. 1

Overzicht kernvragen Schoolverlatersinformatiesysteem

Variabele

Opmerking

Algemeen

Geslacht

Leeftijd

Allochtoon

Toestemming doorgeven gegevens aan school

\section{Onderwijsloopbaan}

Gevolgde opleiding

Voltijd- of deeltijdvariant van gevolgde opleiding

$\mathrm{HBO} / \mathrm{WO}$

Begindatum gevolgde opleiding

Einddatum gevolgde opleiding

Aantal jaren opleiding gevolgd

Diploma of certificaat behaald van gevolgde opleiding

Opnieuw kiezen van gevolgde opleiding

Hoogste vooropleiding

Vervolgopleiding

Voltijd- of deeltijdvariant van vervolgopleiding

Vervolgopleiding diploma/gestopt

Aansluiting vervolgopleiding op gevolgde opleiding

Cursus/bedrijfsopleiding

Cursus/bedrijfsopleiding totale duur

Cursus/bedrijfsopleiding aantal uren per week

$\mathrm{HBO} / \mathrm{WO}$

$\mathrm{HBO} / \mathrm{WO}$

VO/VBO/BOL/BBL

$\mathrm{HBO} / \mathrm{WO}$

niet $\mathrm{VO}$

BOL/BBL/HBO/WO

$\mathrm{HBO} / \mathrm{WO}$

niet WO

$\mathrm{HBO} / \mathrm{WO}$

$\mathrm{HBO} / \mathrm{WO}$

$\mathrm{HBO} / \mathrm{WO}$

\section{Arbeidsmarktintrede}

Maatschappelijke positie sinds schoolverlaten

Actief gezocht naar werk tijdens of na opleiding

Begin actief zoeken naar werk

WO

Betaald werk laatste 4 weken gezocht

$\mathrm{HBO} / \mathrm{WO}$

Op moment werkzoekend

Beschikbaar betaald werk

Reden niet beschikbaar voor betaald werk

VO/VBO/BOL/BBL

$\mathrm{HBO} / \mathrm{WO}$

$\mathrm{HBO} / \mathrm{WO}$

Inschrijving arbeidsbureau

Huidige functie begindatum

WO

Huidige functie werving

$\mathrm{HBO} / \mathrm{WO}$

Huidige functie beroep SBC ' 92

Huidige functie branche SBI ' 93

Huidige functie personeelsomvang bedrijf

Huidige functie vestigingsplaats bedrijf

$\mathrm{HBO} / \mathrm{WO}$

Huidige functie dienstverband

Huidige functie aanstelling

Huidige functie vereist opleidingsniveau volgens werkgever

Huidige functie vereiste opleidingsrichting volgens werkgever

Huidige functie leidinggeven

Huidige functie arbeidsuren per week

Huidige functie bruto maandinkomen

HBO/WO

niet bij VO 
Tabel A. 1 (vervolg)

Overzicht kernvragen Schoolverlatersinformatiesysteem

Variabele

Opmerking

Huidige functie aansluiting met gevolgde opleiding

Nevenfuncties

niet bij VO

Nevenfuncties aantal uren per week

$\mathrm{HBO} / \mathrm{WO}$

Opleiding-huidige functie: belang van kennis en technieken

$\mathrm{HBO} / \mathrm{WO}$

Opleiding-huidige functie: belang van vaardigheden

$\mathrm{BOL} / \mathrm{BBL} / \mathrm{HBO} / \mathrm{WO}$

Opleiding-huidige functie: belang van houdingsaspecten

$\mathrm{BOL} / \mathrm{BBL} / \mathrm{HBO} / \mathrm{WO}$

Opleiding-huidige functie: aandacht voor kennis en technieken

$\mathrm{BOL} / \mathrm{BBL} / \mathrm{HBO} / \mathrm{WO}$

Opleiding-huidige functie: aandacht voor vaardigheden

$\mathrm{BOL} / \mathrm{BBL} / \mathrm{HBO} / \mathrm{WO}$

Opleiding-huidige functie: aandacht voor houdingsaspecten

$\mathrm{BOL} / \mathrm{BBL} / \mathrm{HBO} / \mathrm{WO}$

$\mathrm{BOL} / \mathrm{BBL} / \mathrm{HBO} / \mathrm{WO}$ 


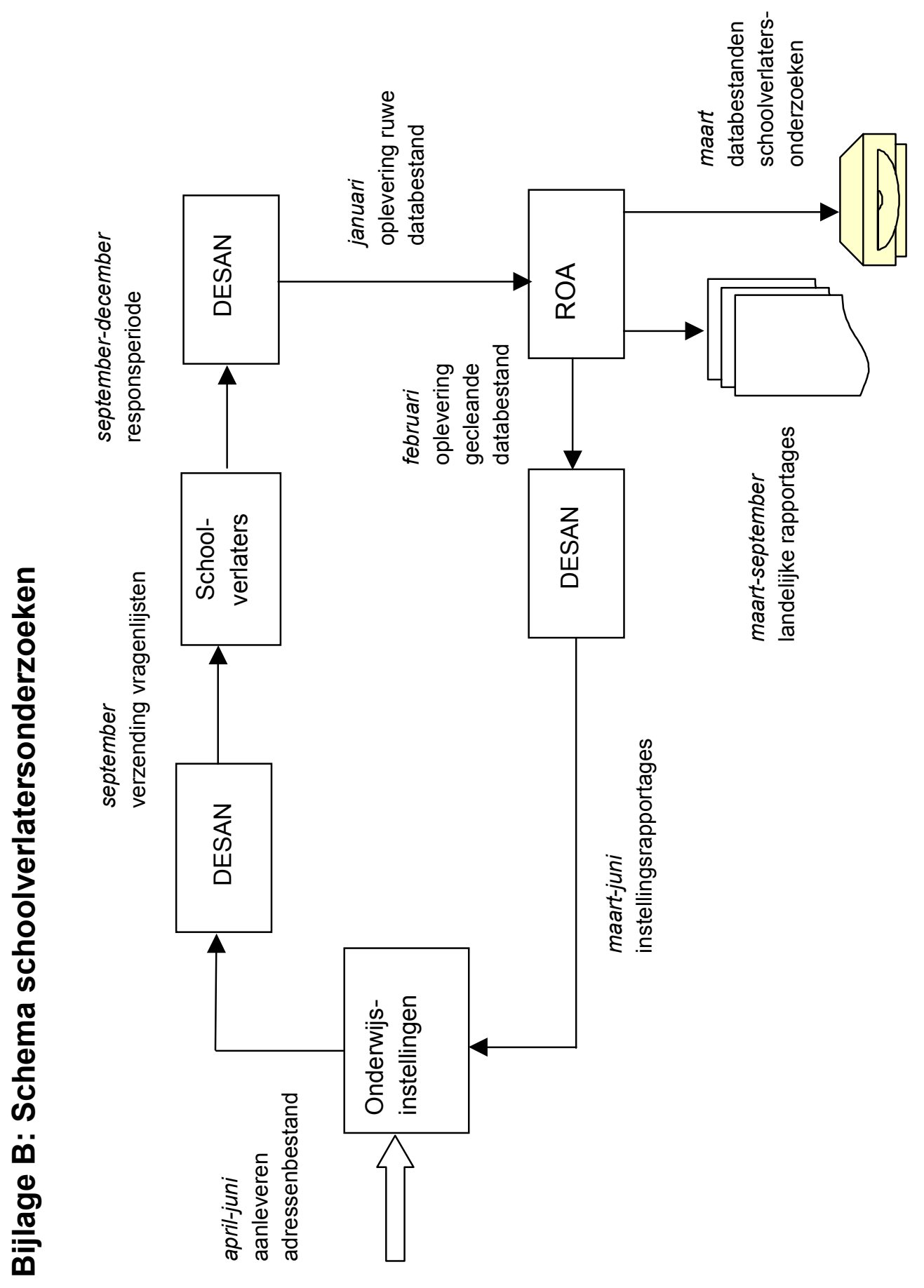




\section{Bijlage C: Competentievragen}

\section{C.1 Competentievragen reguliere vragenlijst}

Hieronder worden enkele aspecten genoemd die voor een goede uitoefening van uw functie van belang kunnen zijn. Beantwoord in het schema de drie onderstaande vragen door het kokje aan te kruisen dat het best past bij uw mening.

a. Gebruik

In welke mate gebruikt $u$ het genoemde aspect in uw werk?

b. Vereist niveau van beheersing

Hoe goed dient $u$ hierbij het genoemde aspect te

beheersen?

c. Waar vooral geleerd

Waar heeft $u$ het genoemde aspect vooral geleerd?

\section{Aspecten}

1. Vakkennis

2. Vakspecifieke methoden en technieken

3. Computergebruik

4. Met cijfers om kunnen gaan

5. Communicatieve vaardigheden

6. Werken in teamverband

7. Plannen en organiseren

8. Leidinggeven

9. Zelfstandigheid

10. Creativiteit

11. Initiatief

12. Omgaan met en inspelen op veranderingen

13. Nauwkeurigheid

14. Internationale oriëntatie

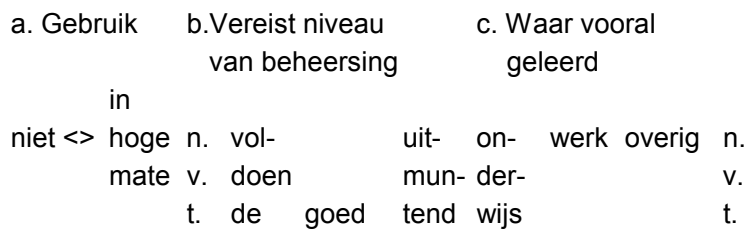

$\begin{array}{lllllllllllll}1 & 2 & 3 & 4 & 5 & 1 & 2 & 3 & 4 & 1 & 2 & 3 & 4 \\ 1 & 2 & 3 & 4 & 5 & 1 & 2 & 3 & 4 & 1 & 2 & 3 & 4 \\ 1 & 2 & 3 & 4 & 5 & 1 & 2 & 3 & 4 & 1 & 2 & 3 & 4 \\ 1 & 2 & 3 & 4 & 5 & 1 & 2 & 3 & 4 & 1 & 2 & 3 & 4 \\ 1 & 2 & 3 & 4 & 5 & 1 & 2 & 3 & 4 & 1 & 2 & 3 & 4 \\ 1 & 2 & 3 & 4 & 5 & 1 & 2 & 3 & 4 & 1 & 2 & 3 & 4 \\ 1 & 2 & 3 & 4 & 5 & 1 & 2 & 3 & 4 & 1 & 2 & 3 & 4 \\ 1 & 2 & 3 & 4 & 5 & 1 & 2 & 3 & 4 & 1 & 2 & 3 & 4 \\ 1 & 2 & 3 & 4 & 5 & 1 & 2 & 3 & 4 & 1 & 2 & 3 & 4 \\ 1 & 2 & 3 & 4 & 5 & 1 & 2 & 3 & 4 & 1 & 2 & 3 & 4 \\ 1 & 2 & 3 & 4 & 5 & 1 & 2 & 3 & 4 & 1 & 2 & 3 & 4 \\ 1 & 2 & 3 & 4 & 5 & 1 & 2 & 3 & 4 & 1 & 2 & 3 & 4 \\ 1 & 2 & 3 & 4 & 5 & 1 & 2 & 3 & 4 & 1 & 2 & 3 & 4 \\ 1 & 2 & 3 & 4 & 5 & 1 & 2 & 3 & 4 & 1 & 2 & 3 & 4\end{array}$




\section{C.2 Competentievragen proeflijst}

Hieronder staat een aantal aspecten die in werk van belang kunnen zijn. Geef voor ieder aspect een inschatting van:

- uw eigen niveau

- (indien van toepassing) het niveau dat vereist is

in uw huidige functie

- waar $\mathrm{u}$ het aspect vooral heeft geleerd

\section{Kennis van:}

a. uw eigen vakgebied

b. andere vakgebieden

\section{Vermogen om:}

c. uw vakkennis in de praktijk toe te passen

d. informatie- \& communicatietechnologie te gebruiken

e. in buitenlandse talen te communiceren

f. informatie te vergaren

g. problemen en kansen te signaleren

h. verbanden te leggen tussen verschillende zaken

i. hoofd- van bijzaken te onderscheiden

j. logisch te redenen

k. conform budget, planning of richtlijnen te werken

I. onder druk goed te functioneren

m. knopen door te hakken

n. nieuwe ideeën en oplossingen te bedenken

o. nieuwe dingen te leren

p. aan anderen duidelijk te maken wat u bedoelt

q. productief met anderen samen te werken

r. capaciteiten van anderen aan te spreken

s. zelfstandig de werkzaamheden uit te voeren Bereidheid om:

t. uw nek uit te steken

u. ideeën van uzelf en anderen ter discussie te stellen

v. op te komen voor uw eigen standpunt

w. begrip te tonen voor andere standpunten

Afgerond cijfer tussen Aspect vooral geleerd 1 en 10 voor

$\begin{array}{ccccc}\text { uw eigen } & \text { het vereist } & \text { buiten de } & & \text { in de } \\ \text { niveau } & \text { niveau in uw } & \text { opleiding } & <-> & \text { opleiding }\end{array}$
huidige functie

\begin{tabular}{|c|c|c|c|c|}
\hline & & 1 & 2 & 3 \\
\hline & $\ldots \ldots$ & 1 & 2 & 3 \\
\hline & $\ldots \ldots \ldots$ & 1 & 2 & 3 \\
\hline .......... & .......... & 1 & 2 & 3 \\
\hline$\ldots \ldots$ & .......... & 1 & 2 & 3 \\
\hline & $\ldots \ldots \ldots$ & 1 & 2 & 3 \\
\hline & $\ldots \ldots \ldots$ & 1 & 2 & 3 \\
\hline .......... & $\ldots \ldots \ldots$ & 1 & 2 & 3 \\
\hline$\ldots$. & $\ldots \ldots \ldots$ & 1 & 2 & 3 \\
\hline …… & .......... & 1 & 2 & 3 \\
\hline & $\ldots \ldots \ldots$ & 1 & 2 & 3 \\
\hline & $\ldots \ldots \ldots$ & 1 & 2 & 3 \\
\hline & .......... & 1 & 2 & 3 \\
\hline .. & $\ldots \ldots \ldots$ & 1 & 2 & 3 \\
\hline$\ldots \ldots \ldots$ & $\ldots \ldots \ldots$ & 1 & 2 & 3 \\
\hline$\ldots \ldots$ & $\ldots \ldots \ldots$ & 1 & 2 & 3 \\
\hline$\ldots \ldots$ & $\ldots \ldots \ldots$ & 1 & 2 & 3 \\
\hline & & 1 & 2 & 3 \\
\hline & ......... & 1 & 2 & 3 \\
\hline$\ldots \ldots$ & $\ldots \ldots \ldots$ & 1 & 2 & 3 \\
\hline & $\ldots \ldots \ldots$ & 1 & 2 & 3 \\
\hline$\cdots$ & .......... & 1 & 2 & 3 \\
\hline$\ldots \ldots$ & $\ldots \ldots \ldots$ & 1 & 2 & 3 \\
\hline
\end{tabular}

